DOI https://doi.org/10.30525/978-9934-26-173-2-21

\title{
РОЛЬ ВИКЛАДАЧА В ОРГАНІЗАЦІї НАУКОВО-ДОСЛІДНИЦЬКОЇ ДІЯЛЬНОСТІ СТУДЕНТА
}

\author{
Погоріла I. O. \\ кандидат педагогічних наук, доцент, \\ доиент кафедри біології \\ Національний медичний університет імені О. О. Богомольияя \\ м. Київ, Україна
}

Якість виконання науково-дослідної роботи студента закладу вищої освіти, зокрема медичного, залежить від багатьох факторів, зокрема індивідуальних властивостей особистості, бажання самого дослідника, його мотивації, готовності до організації і проведення науковопошукової діяльності тощо [1, с. 264]. Також важлива роль викладача, який здійснює керівництво науково-дослідницькою діяльністю студента - майбутнього науковця.

У Національному медичному університеті імені О.О. Богомольця керівництво науково-дослідницькою діяльністю студента здійснюється викладачами в межах студентського наукового гуртка кафедри біології. Науковий гурток кафедри біології об'єднує студентів різних курсів, починаючи 3 першого, та різних факультетів, зокрема медичного, стоматологічного, фармацевтичного, медико-психологічного тощо.

Саме викладач має побачити творчі здібності та розкрити творчий потенціал студента-першокурсника, його інтелектуальну активність, ознайомити 3 технологією наукового дослідження, 3 правилами оформлення результатів наукового пошуку, проведенням творчих звітів. Педагог здійснює теоретичну підготовку майбутнього науковця, який прагне займатися творчою пошуковою діяльністю, а саме допомагає у визначенні мети, завдань, актуальності дослідження, формулюванні висновків, підготовці презентацій [1, с. 265]. Тому на засіданнях студентського наукового гуртка кафедри біології Національного медичного університету імені О.О. Богомольця 3 метою включення студентів у науково-дослідницьку діяльність, проводяться міні-лекції, практикуми, де висвітлюються теоретичні аспекти науководослідницької діяльності, зокрема ознайомлення із структурою наукової статті, бібліографічним оглядом наукової літератури, визначенням об'єкта і предмета дослідження, методами дослідження, сучасними методами статистичної обробки отриманих результатів дослідження, 
теоретичною новизною та практичним значенням, поняттями про нульову гіпотезу та контрольну групу тощо.

Важлива суб'єкт-суб'єктна взаємодія між викладачем та студентом, толерантність у спілкуванні, повага до особистості студента [2, с. 149]. Педагогу закладу вищої освіти, зокрема медичного доцільно враховувати інтереси та потреби вихованця, його працездатність, а також підтримувати ентузіазм та ініціативу майбутнього науковця. Студентдослідник перш за все має бачити у своєму наставнику порядну, щиру, чесну, справедливу, доброзичливу, гуманну, відкриту людину, яка готова зрозуміти, підтримати, допомогти своєму вихованцю, залучити його до співпраці.

Викладачу закладу вищої освіти, який здійснює керівництво науководослідницькою діяльністю студента, зокрема медика, доцільно дбати про здоров'я майбутнього науковця, не перенавантажувати його, створювати ситуацію успіху, комфортну атмосферу, щоб науково-дослідницька робота приносила задоволення і не заважала навчанню, особливо це стосується новачків-першокурсників, яким ще важко правильно розподілити час. Тому педагогу-консультанту необхідно обов'язково звертати увагу студентів-гуртківців на дотриманні режиму праці i відпочинку. В той же час студенту як майбутньому науковцю потрібен сучасний, освічений педагог, фахівець, професіонал своєї справи.

Педагог-консультант кафедри біології не тільки бере участь у засіданнях студентського наукового гуртка. Виступаючи в ролі наставника, викладач багато індивідуально працює зі студентомгуртківцем. Тому важливо бути прикладом для своїх вихованців. Недопустимі авторитарність, грубість, наявність шкідливих звичок тощо [3, с. 192]. Ерудит, інтелігент, всебічно розвинута особистість, 3 широким колом інтересів, цікавий співрозмовник - саме такий педагог викликає повагу у студентів - гуртківців. Саме такий керівник здатний викликати інтерес у своїх вихованців до пошукової діяльності та прокласти їм шлях у науку.

Отже, здійснюючи керівництво науково-дослідницькою діяльністю студента, педагог має виступати не стільки в якості організатора, скільки в якості консультанта, координатора, який здійснює індивідуальне спостереження, забезпечує оптимізацію праці майбутнього науковця.

\section{Література:}

1. Вітвицька С.С. Основи педагогіки вищої школи: Підручник за модульно-рейтинговою системою навчання для студентів магістратури. - Київ: Центр навчальної літератури, 2006. - 248 с. 
2. Кайдалова Л.Г. та ін. Педагогіка та психологія вищої школи: навчальний посібник / Л.Г. Кайдалова, І.С. Сабатовська-Фролкіна, Н.В. Альохіна, Н.В. Шварп. - Х. : НФаУ, 2019 - 248 с.

3. Гладуш В.А. Педагогіка вищої школи: теорія, практика, історія. Навч.посіб. / В.А. Гладуш, Г.І. Лисенко - Д., 2014. - 416 с.

DOI https://doi.org/10.30525/978-9934-26-173-2-22

\title{
ДИСТАНЦЙНЕ НАВЧАННЯ: СУЧАСНИЙ ФОРМАТ ОСВІТИ
}

\author{
Пухальська О. М. \\ викладач комісії автоматизації та електроустаткування \\ ВСП «Дніпровський фаховий коледж інженерії та педагогіки \\ ДВНЗ УДХТУ» \\ Манейло О. Ю. \\ викладач комісії економічних дисциплін \\ ВСП «Дніпровський фаховий коледж інженерії та педагогіки \\ ДВНЗ УДХТУ» \\ м. Кам'янське, Україна
}

Пандемія коронавірусу значно вплинула на навчальний процес у всьому світі. Немає сумнівів, що онлайн-курси та дистанційні методики навчання - справді на часі.

Дистанційне навчання в Україні реалізується через систему дистанційного навчання (СДН), яка є частиною системи освіти України, 3 нормативно-правовою базою, організаційно оформленою структурою, кадровим, системотехнічним, матеріально-технічним та фінансовим забезпеченням, що реалізує дистанційне навчання на рівнях загальної середньої, професійно-технічної, вищої та післядипломної освіти, а також самоосвіти [1].

Під дистанційним навчанням розуміється індивідуалізований процес набуття знань, умінь, навичок і способів пізнавальної діяльності людини, який відбувається в основному за опосередкованої взаємодії віддалених один від одного учасників навчального процесу у спеціалізованому середовищі, яке функціонує на базі сучасних психолого-педагогічних та інформаційно-комунікаційних технологій [1].

Основними видами навчальних занять при дистанційному навчанні у вищих навчальних закладах є: 